Article

\title{
Anti-Amoebic Properties of Carbonyl Thiourea Derivatives
}

\author{
Maizatul Akma Ibrahim, Mohd Sukeri Mohd Yusof and Nakisah Mat Amin * \\ School of Fundamental Science, Universiti Malaysia Terengganu, Kuala Terengganu, \\ Terengganu 21030, Malaysia; E-Mails: maironan@yahoo.com (M.A.I.); \\ mohdsukeri@umt.edu.my (M.S.M.Y.) \\ * Author to whom correspondence should be addressed; E-Mail: nakisah@umt.edu.my; \\ Tel.: +609-668-3245; Fax: +609-668-3608.
}

Received: 26 November 2013; in revised form: 25 March 2014 / Accepted: 9 April 2014 / Published: 22 April 2014

\begin{abstract}
Thiourea derivatives display a broad spectrum of applications in chemistry, various industries, medicines and various other fields. Recently, different thiourea derivatives have been synthesized and explored for their anti-microbial properties. In this study, four carbonyl thiourea derivatives were synthesized and characterized, and then further tested for their anti-amoebic properties on two potential pathogenic species of Acanthamoeba, namely A. castellanii (CCAP 1501/2A) and A. polyphaga (CCAP 1501/3A). The results indicate that these newly-synthesized thiourea derivatives are active against both Acanthamoeba species. The $\mathrm{IC}_{50}$ values obtained were in the range of 2.39-8.77 $\mu \mathrm{g} \cdot \mathrm{mL}^{-1}(9.47-30.46 \mu \mathrm{M})$ for $A$. castellanii and $3.74-9.30 \mu \mathrm{g} \cdot \mathrm{mL}^{-1}$ (14.84-31.91 $\mu \mathrm{M}$ ) for A. polyphaga. Observations on the amoeba morphology indicated that the compounds caused the reduction of the amoeba size, shortening of their acanthopodia structures, and gave no distinct vacuolar and nuclear structures in the amoeba cells. Meanwhile, fluorescence microscopic observation using acridine orange and propidium iodide (AOPI) staining revealed that the synthesized compounds induced compromised-membrane in the amoeba cells. The results of this study proved that these new carbonyl thiourea derivatives, especially compounds M1 and M2 provide potent cytotoxic properties toward pathogenic Acanthamoeba to suggest that they can be developed as new anti-amoebic agents for the treatment of Acanthamoeba keratitis.
\end{abstract}

Keywords: thiourea derivatives; anti-amoebic agent; Acanthamoeba; Acanthamoeba keratitis; morphology; membrane integrity 


\section{Introduction}

Acanthamoeba is one of the free-living amoebae that are widely distributed in the environment [1]. This amoeba genus is among the most common protozoa to be found in soil and water samples [2]. Acanthamoeba is known as the causative agent for a sight-threatening disease, Acanthamoeba keratitis. This eye infection is recognized as one of the most challenging and severe ocular parasitic diseases [3]. The Acanthamoeba species which have been reported to cause Acanthamoeba keratitis are A. castellanii, A. polyphaga, A. hatchetti, A. culbertsoni, A. rhysodes, A. griffini, A. quina, and A. lugdunensis [4]. An effective medical therapy for treating the infection is currently not available. Several antiseptics such as chlorhexidine gluconate and polyhexamethylene biguanide have been used to lessen the symptoms [5,6], but they are not specifically designed to treat the ocular disease, thus side effects are frequently reported [7,8]. Some surveys showed that Acanthamoeba are resistant to these agents, which make them less effective $[9,10]$ especially at later stages of infection. Therefore, new potential agents are in high demand to assist the current treatment of Acanthamoeba keratitis.

Since synthetic organic compounds are being widely designed nowadays in parallel with the development of combinatorial chemistry and compound libraries, they could be exploited for the development of new drugs. Some synthetic compounds such as quinoxaline derivatives and thiosemicarbazone analogs were investigated on the cells of Entamoeba histolytica and found to display beneficial properties which can be developed as anti-amoebic agents [11,12]. Thiourea, which is one of the earliest synthetic organic compounds, has been globally used directly and indirectly due to its ready availability. This factor has attracted researchers to evaluate thiourea-based compounds from their safety point of view [13] and potential medical properties [14-16].

Previous studies have shown the potential of certain thiourea derivatives as anti-microbial agents $[17,18]$. Drugs which are based on thiourea have also been used clinically to treat patients of tuberculosis [19] and thyroid conditions [20]. Therefore, in the present study, four new carbonyl thiourea derivatives were synthesized and characterized, and could possibly be developed as new agent to treat Acanthamoeba keratitis after their anti-amoebic properties were examined. Cytotoxicity tests which involved investigation of the inhibition of amoeba population and disruption of the amoeba membrane integrity caused by the compounds were conducted. Microscopic observation was also carried out to examine the morphological alterations in the amoeba cells caused by these newly-synthesized compounds.

\section{Results and Discussion}

\subsection{Preparation of Carbonyl Thiourea Derivatives}

The preparation of compounds M1-M4 is shown in Scheme 1 [21,22], while the compounds obtained and their molecular weights are listed in Table 1.

\subsection{Anti-Amoebic Properties: $I C_{50}$ Values}

Experiments were carried out to analyze the in vitro anti-amoebic activity of the four newlysynthesized carbonyl thiourea derivatives on two pathogenic species of Acanthamoeba, namely 
A. castellanii (CCAP 1501/2A) and A. polyphaga (CCAP 1501/3A). The amoebae were obtained from the UK Culture Collection of Algae and Protozoa (CCAP, Argyll, UK). The $\mathrm{IC}_{50}$ values which were obtained from the absorbance readings and represented in non-linear sigmoidal dose-response curve derived from GraphPrism software are presented in Table 2.

Scheme 1. Synthesis of carbonyl thiourea compounds.

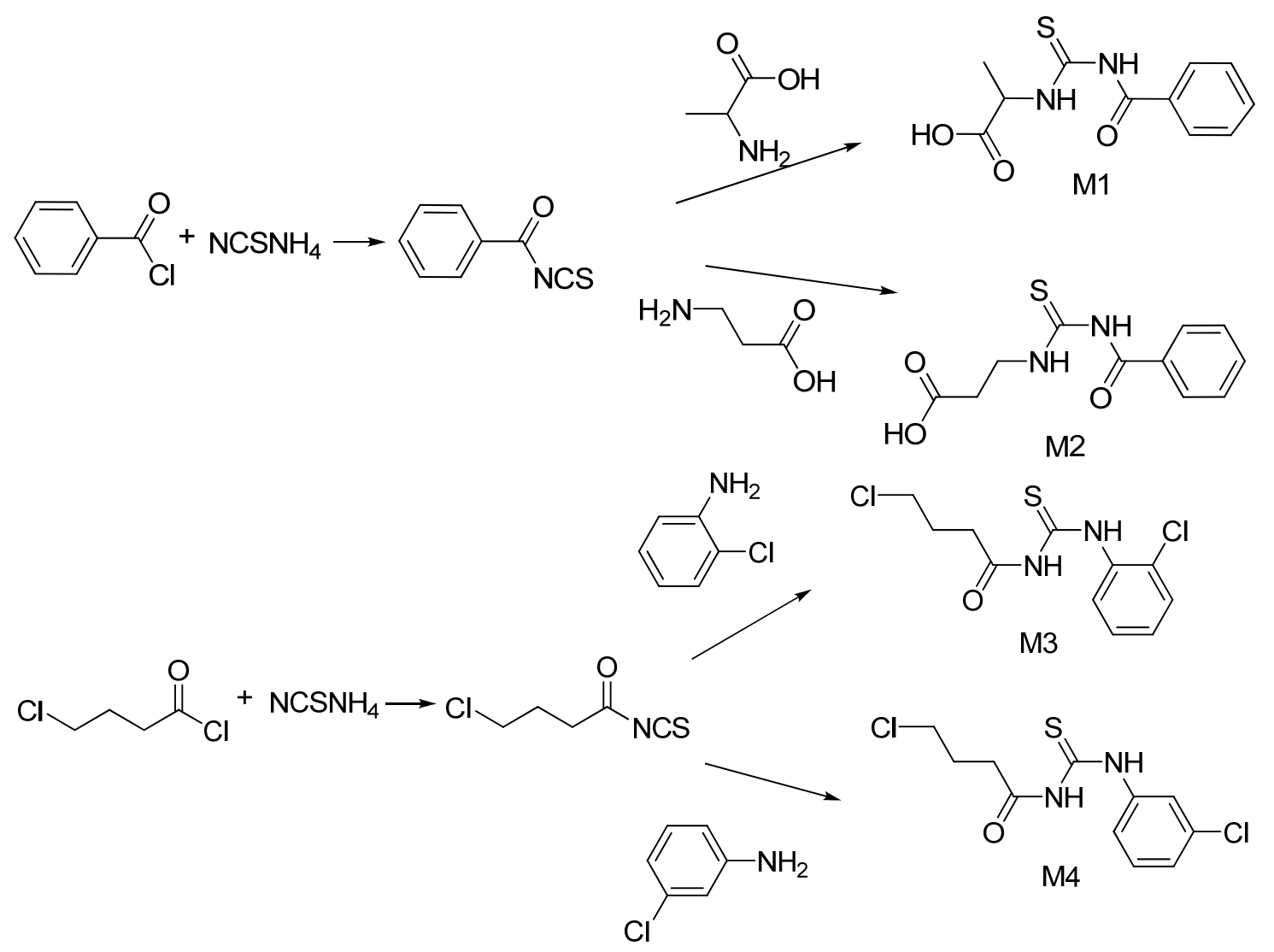

Table 1. The molecular structures of the newly-synthesized carbonyl thiourea derivatives.

\begin{tabular}{llll}
\hline Code & Chemical name & MW & Molecular structure \\
$\mathbf{M 1}$ & 2-(3-Benzoylthioureido)propanoic acid & 252.29 \\
$\mathbf{M} 2$ & 3-(3-Benzoylthioureido)propanoic acid & & \\
M3 & $N$-(2-Chlorophenyl)- $N^{\prime}$-(4-chlorobutanoyl)thiourea & 291.20
\end{tabular}


Table 2. The $\mathrm{IC}_{50}$ values of the newly-synthesized thiourea derivatives against Acanthamoeba and their comparative strength (\%) as compared with the positive control, chlorhexidine.

\begin{tabular}{|c|c|c|c|c|}
\hline \multirow[b]{2}{*}{ Compound } & \multicolumn{4}{|c|}{$\mathrm{IC}_{50}\left(\mu \mathrm{g} \cdot \mathrm{mL}^{-1}\right)$} \\
\hline & \multicolumn{2}{|c|}{$\begin{array}{c}\text { A. castellanii } \\
\text { (CCAP 1501/2A) }\end{array}$} & \multicolumn{2}{|c|}{$\begin{array}{c}\text { A. polyphaga } \\
\text { (CCAP 1501/3A) }\end{array}$} \\
\hline M1 & \multicolumn{2}{|c|}{$2.39 \pm 0.24$} & \multicolumn{2}{|c|}{$3.74 \pm 0.44$} \\
\hline M2 & \multicolumn{2}{|c|}{$3.34 \pm 0.41$} & \multicolumn{2}{|c|}{$3.76 \pm 0.27$} \\
\hline M3 & \multicolumn{2}{|c|}{$8.07 \pm 0.65$} & \multicolumn{2}{|c|}{$8.52 \pm 0.81$} \\
\hline \multirow[t]{3}{*}{ M4 } & 8.87 & .27 & 9.30 & \\
\hline & \multicolumn{4}{|c|}{$I C_{50}(\mu M)$} \\
\hline & $\begin{array}{c}\text { A. castellanii } \\
\text { (CCAP 1501/2A) }\end{array}$ & $\begin{array}{c}\text { Percentage of } \\
\text { strength }(\%)\end{array}$ & $\begin{array}{c}\text { A. polyphaga } \\
\text { (CCAP 1501/3A) }\end{array}$ & $\begin{array}{c}\text { Percentage of } \\
\text { strength }(\%)\end{array}$ \\
\hline M1 & 9.47 & 73.5 & 14.84 & 52.4 \\
\hline M2 & 13.24 & 52.6 & 14.90 & 52.1 \\
\hline M3 & 27.70 & 25.1 & 29.25 & 26.6 \\
\hline M4 & 30.46 & 22.9 & 31.91 & 24.3 \\
\hline Chlorhexidine & 6.96 & 100.0 & 7.77 & 100.0 \\
\hline
\end{tabular}

All compounds used in the present study have high anti-amoebic activity against Acanthamoeba with $\mathrm{IC}_{50}$ values in the range from 2.39 to $8.87 \mu \mathrm{g} \cdot \mathrm{mL}^{-1}$ for $A$. castellanii, and 3.74 to $9.30 \mu \mathrm{g} \cdot \mathrm{mL}^{-1}$ for $A$. polyphaga, which are equivalent to $9.47-30.46 \mu \mathrm{M}$ and $14.84-31.91 \mu \mathrm{M}$ respectively (Table 2). These derivatives were thus observed to be active against $A$. castellanii and moderately active toward A. polyphaga based on compounds classification for the protozoan cells proposed by Deharo [23]. This means that $A$. castellanii is more susceptible towards the series of newly-synthesized carbonyl thiourea compounds compared to A. polyphaga. McBride et al. [24], in their study of drug efficacy, also noted that A. polyphaga was more resistant compared to A. castellanii, confirming the data obtained in the present study. The strength of chlorhexidine, a positive control in this study against Acanthamoeba was considered as $100 \%$ and its $\mathrm{IC}_{50}$ value was $6.96 \mu \mathrm{M}$ for $A$. castellanii and $7.77 \mu \mathrm{M}$ for A. polyphaga. The $t$-test analysis for the absorbance readings of untreated and treated amoebae showed statistically significant differences $(p<0.05)$.

Thiourea in its basic structure has one sulfur atom, which has six valence electrons and its electronic configuration is similar to that of oxygen [25]. The amino acid type of thiourea derivatives labeled as M1 and M2 in this study showed higher anti-amoebic activity. Their strength as compared with chlorhexidine against both species of Acanthamoeba is shown in Table 2. This indicates that the amino acid moieties in $\mathbf{M} 1$ and $\mathbf{M} 2$ could enhance the activity of thiourea derivatives against Acanthamoeba cells. Fustero et al. [26] supported this finding by highlighting that in general, amino acid derivatives of compounds can exhibit a variety of biological properties. Meanwhile, Ye et al. [27] emphasized that amino acids derivatives in compounds would give them a hydrophilic moiety which leads to high selectivity toward receptors. This suggests that the mechanism of action for the proposed thiourea derivatives toward the protozoan parasite Acanthamoeba should focus on the hydrophobicity of thiourea molecules to explain their actions. The suggested drug-receptors for the compounds' main target in the amoeba cells are the transport proteins that are distributed throughout the cell membrane. This explains that the thiourea chemical molecules' preliminary penetration into Acanthamoeba is 
through its membrane. However, the detail of the mechanism of action of the amino acid group toward the amoeba cells is poorly understood.

Compounds M3 and M4 contain one chloride halogen atom in their benzene rings. The presence of these halogens contributes to the compounds' activity against Acanthamoeba. Patel and Shaikh [28] reported that several compounds containing chlorine atom had better anti-microbial activity compared to compounds without the halogen atom. Furthermore, the presence of chlorine in chlorhexidine was proven to contribute in its anti-amoebic activity. However, the anti-amoebic activity of compounds M3 and M4 in this study were non-comparable to M1 and M2 that contain amino acid groups which gave stronger in actions against the tested amoeba cells.

\subsection{Morphological Changes in Acanthamoeba}

The morphological structures of untreated, as well as thiourea- and chlorhexidine-treated Acanthamoeba of both species are shown in Figures 1 and 2. The untreated cells exhibited distinct structures of acanthopodia, vacuoles and nuclei. Meanwhile, for the thiourea-treated Acanthamoeba, vacuoles and nucleus were not apparent, and the cells were also observed to be smaller in size. The morphology of treated Acanthamoeba became rounded due to shortening and loss of their acanthopodia structures, which eventually caused the amoeba cells to detach from the well's surface and float in the culture medium.

Figure 1. Light microscopy of $A$. castellanii (a) Untreated cells with obvious acanthapodia structures on the cells surface (arrows); (b) M1-treated cells; (c) M2-treated cells; (d) M3-treated cells; (e) M4-treated cells; (f) Chlorhexidine-treated cells. Nucleus (n); vacuoles (v). Magnification 300×.
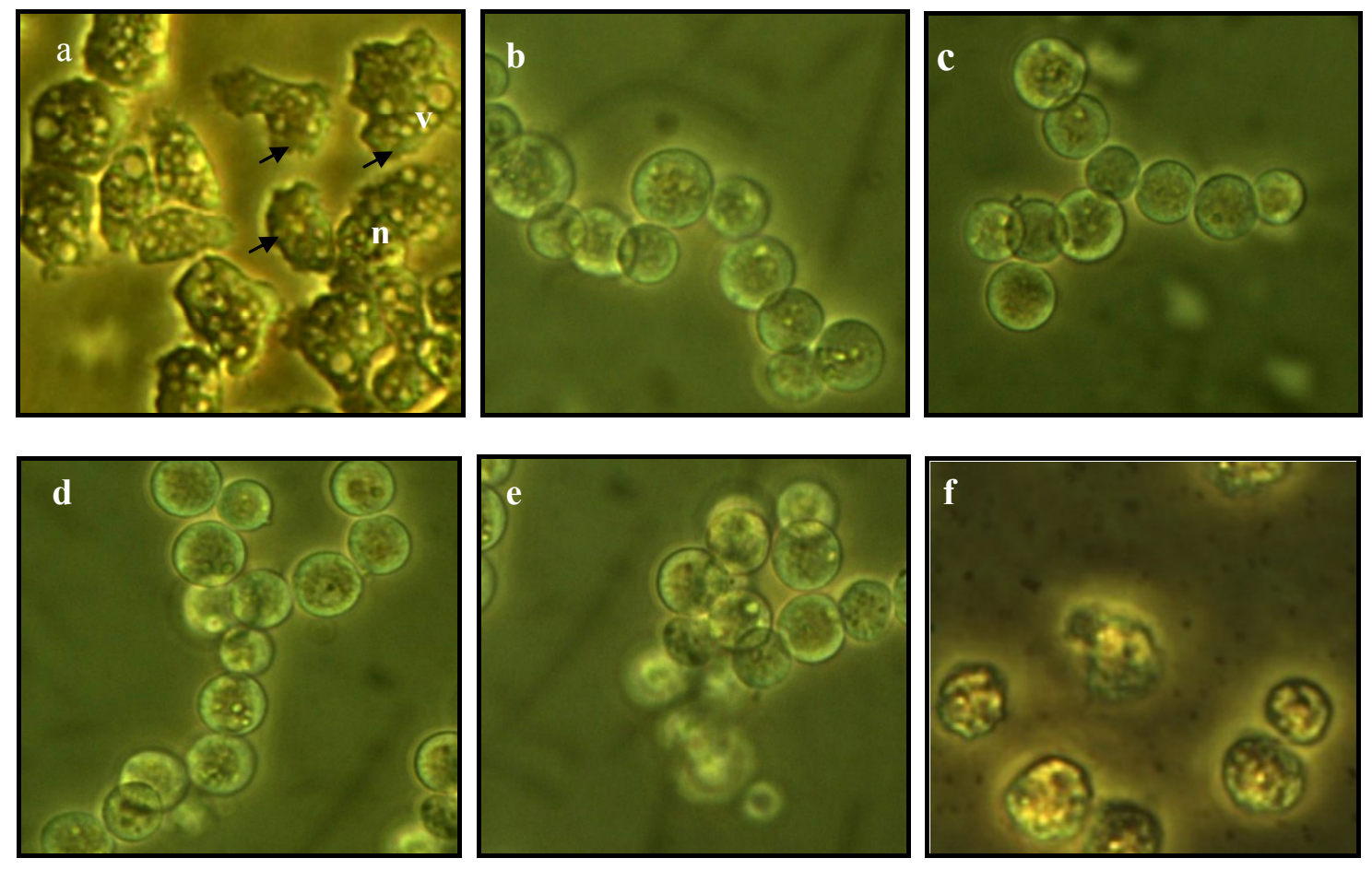
Figure 2. Light microscopy of $A$. polyphaga. (a) Untreated cells; (b) M1-treated cells with acanthapodia structures on the cells surface (arrows); (c) M2-treated cells; (d) M3-treated cells; (e) M4-treated cells; (f) Chlorhexidine-treated cells. Nucleus (n); vacuoles (v). Magnification 300×.
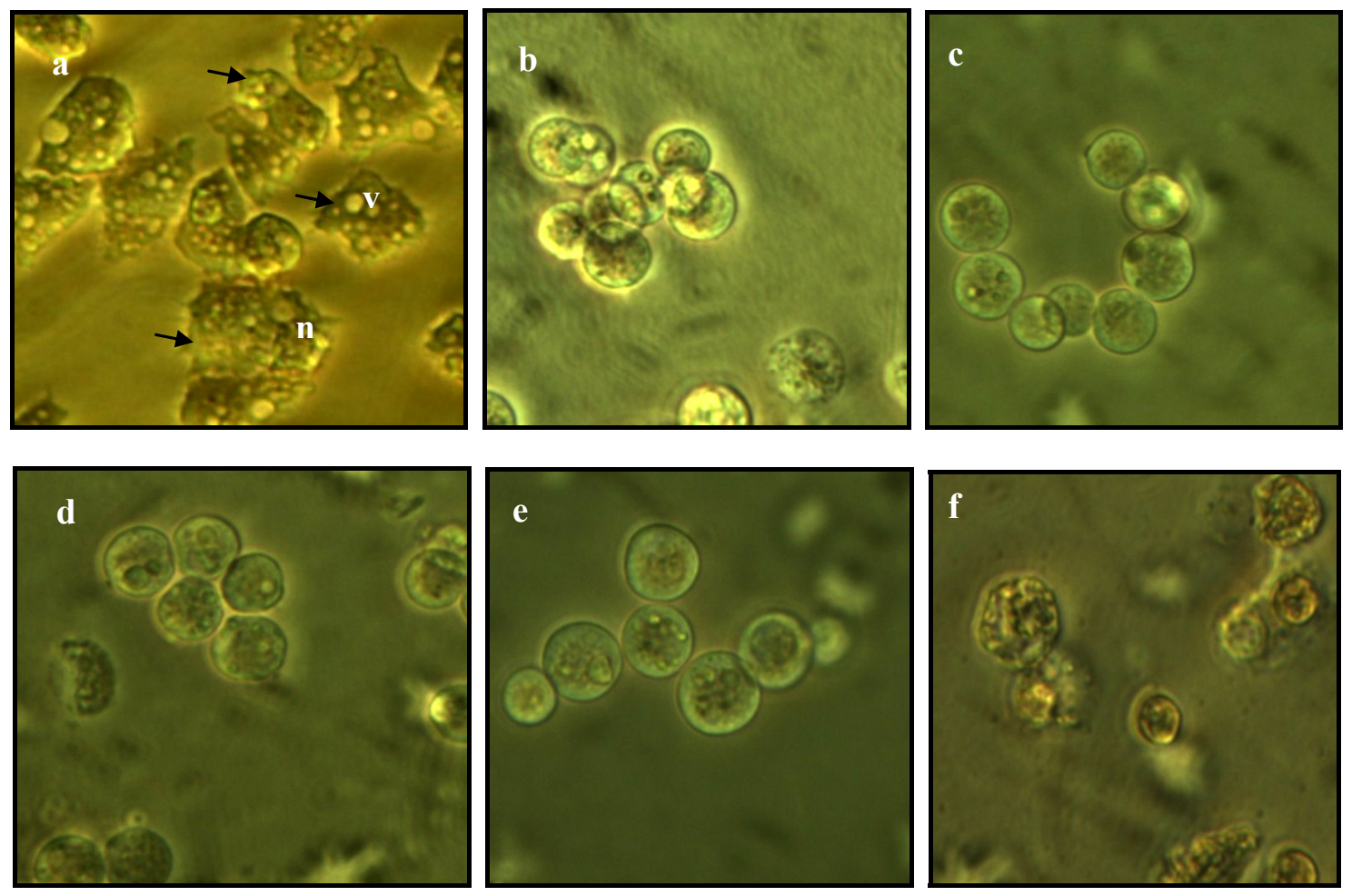

Acanthopodia are important for amoebas' adherence to surfaces, cellular movements and capturing food particles [29]. The alteration of acanthopodia structures as induced by thiourea derivatives in the present study indicates a significant effect on the biology of protozoan cells. These structures also play a key role in Acanthamoeba pathogenesis of amoebic keratitis by modulating a binding to the corneal epithelium of the human host. This leads to secondary events such as interference with host intracellular signaling pathways and toxic secretions from Acanthamoeba which phagocytose host cells that ultimately leads to cell death [30]. With impaired acanthopodia, the pathogenesis of Acanthamoeba will be affected. The thiourea-treated cells were also observed without distinct nucleus. Prominent vacuoles were seen in healthy Acanthamoeba cells but not in the treated amoeba, where its function is to expel water as well as be involved in osmotic regulation that helps the cells move and capture food [31].

After treatment with the thiourea derivatives Acanthamoeba were also reduced in size and became rounded and displayed a cystic appearance. This suggests that the compounds induce encystment in Acanthamoeba. Encystment is a process that involves a drastic reorganization of the subcellular structure of the amoeba cell in which acanthopodia, nucleus and vacuoles disappear. In this stage, the trophozoite condensed itself into a rounded structure with a decrease in cytoplasmic mass, whereby excess food, water and particulate matter are expelled. This was accompanied by the synthesis of a structurally complex double layer wall cyst to help amoeba survive in hostile conditions [32]. Throughout the course of the encystment process, the respiration rates and intracellular ATP levels of cells will be diminished. The cellular levels of RNA, proteins, triacylglyceridases and glycogen will 
also decline substantially. This would result in a decreased cellular volume and dry weight [33]. As a conclusion, with the treatment of the carbonyl thiourea, Acanthamoeba became inactivated, making them unable to affect the host cells during pathogenesis. Chlorhexidine gave comparable effects on the morphology of Acanthamoeba as shown by the thiourea derivatives.

\subsection{Integrity of Acanthamoeba Membrane}

Acanthamoeba trophozoites consist of a plasma membrane which is a thin layer that surrounds the cells and is comprised of phospholipids (25\%), proteins (33\%), sterols (13\%), and lipophosphonoglycans (29\%) [31], while the cytoplasm of Acanthamoeba possesses large numbers of fibrils, glycogen, lipid droplets, and a variety of lysosomal enzymes such as $\alpha$ - and $\beta$-glycosidases, amylase, $\beta$-galactosidase, $\beta$ - $N$-acetylglucosaminidase, $\beta$-glucuronidase, protease, phosphatase, hydrolase acid, RNAse, and DNAse [33]. In all living cells, membrane integrity is essential in maintaining their internal part in order to keep them viable. Compounds with cytotoxic effects would often lead to compromised membrane integrity [34]. Disturbed membrane integrity would disrupt the physiology of the cells' inner state as well as organelles normal functions. In this study, fluorescence microscopic observation based on a dual staining technique was conducted to evaluate the integrity of the amoeba membrane with the given treatment. Acridine orange/propidium iodide (AO/PI) simultaneous staining was applied to distinguish between cells of intact membrane with compromisedmembrane integrity as shown in Figures 3 and 4.

Figure 3. Fluorescence micrographs of $A$. castellanii stained with AO/PI. (a) Untreated cells; (b) M1-treated cells; (c) M2-treated cells; (d) M3-treated cells; (e) M4-treated cells; (f) Chlorhexidine-treated cells. Membrane blebbings were observed in all compound-treated amoebae (arrows). Magnification 300×.
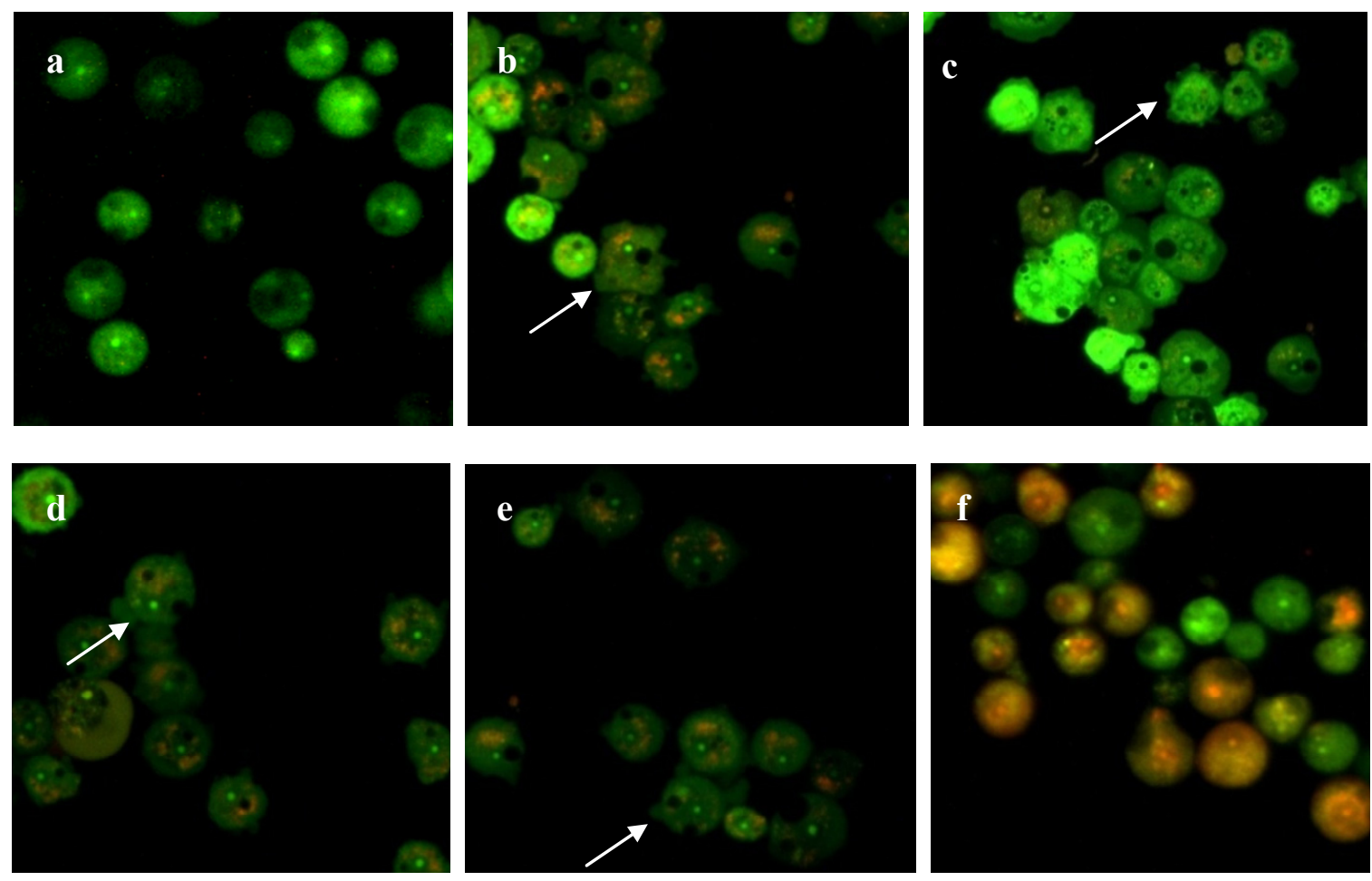
Figure 4. Fluorescence micrographs of $A$. polyphaga stained with AO/PI. (a) Untreated cells; (b) M1-treated cells; (c) M2-treated cells; (d) M3-treated cells; (e) M4-treated cells; (f) Chlorhexidine-treated cells. Membrane blebbings were observed in all compound-treated amoebae (arrows). Magnification 300×.
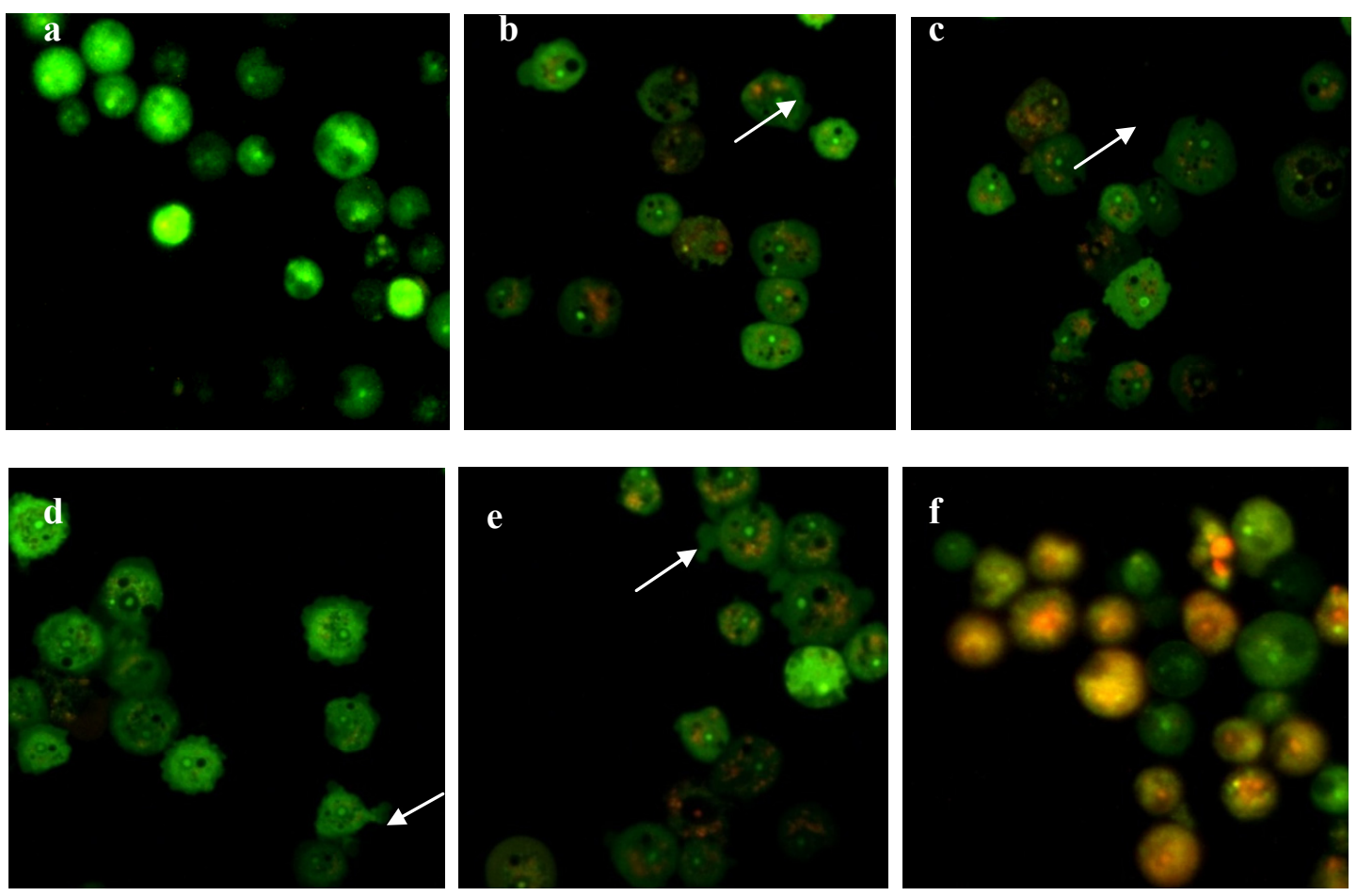

$\mathrm{AO}$ is technically an intercalating agent which can bind to the double strand structure of DNA by intercalating inside the double helix structure. It stains cells with green fluorescence under fluorescence microscopy. AO uptake is the result of an active proton pump in the lysosome of healthy cells. High proton concentration gives AO the ability to enter the uncharged lysosome. The stain becomes protonated and later trapped in the organelles of viable cells [35]. AO is defined as a membrane-permeable dye which can readily enter internal parts of Acanthamoeba through noncompromised membrane integrity. On the other hand, PI is a cationic and an impermeable dye thus excluded from entering normal healthy cells. PI can only traverse and stain cells' intracellular components from leakage and pores formed in membranes [36]. According to Arnkt-Jovin and Jovin [37], when PI is bound to nucleic acids, its orange fluorescence is enhanced 20 to 30 -fold and can be observed well under a fluorescence microscope.

From these principles, the integrity of Acanthamoeba membranes after being treated with thiourea derivatives could be evaluated (Figures 3 and 4). Under fluorescence microscopy, the untreated Acanthamoeba appeared as green fluorescent cells, indicating that they were viable cells with intact membrane structures which only allowed the diffusion of AO through their membranes. On the other hand, the thiourea-treated amoebae exhibited membrane blebbing with orange fluorescence bits in their cytoplasms which were distinguishable from the untreated viable cells. Therefore, the four synthetic compounds used in the present study were proven to disrupt the integrity of amoeba membranes. Meanwhile, chlorhexidine-treated Acanthamoeba also showed compromised membranes by displaying an orange fluorescence color. However, complete orange fluorescence was observed in cells treated 
with chlorhexidine, suggesting that the agent caused total leakage of Acanthamoeba membranes. Under fluorescence microscopy, when both dyes are used simultaneously on compromised cell membranes, an orange color fluorescence will be emitted from the cells due to stronger action of PI compared to $\mathrm{AO}[38]$.

Perrine et al. [39] studied the lethal effects of amidine compounds toward Acanthamoeba and showed that protonated substituents attached to compounds interact with the amphipathic lipids of amoeba's plasma membrane bilayer. This could induce the membrane's structural changes which lead to the modifications of the cell membrane permeability. From this study, it is suggested that the penetration across the Acanthamoeba membrane by the compounds reflects the lipophilic properties of the newly-synthesized thiourea derivative compounds. Nakisah et al. [40] used the same AO/PI staining technique to explain the mode of cell death promoted by crude extracts from Malaysian marine sponges on $A$. castellanii.

\section{Experimental}

\subsection{General Information}

All the compounds utilized in this work were commercially available Merck, Darmstadt, Germany and use as supplied with no further purification. The infrared spectrum (IR) of the product ( $\mathrm{KBr}$ pellets) was recorded using a Perkin Elmer Spectrum GX spectrophotometer (Perkin Elmer, Waltham, MA, USA) in the range of $400-4000 \mathrm{~cm}^{-1}$. NMR spectra were recorded on a Bruker Ultrashield $400 \mathrm{MHz}$ NMR spectrometer using $\mathrm{CDCl}_{3}$ as the solvent.

\subsection{Synthesis of Carbonyl Thiourea Derivatives}

The method to prepare M1-M2 was based on Yusof and Yamin [21], while compounds M3 and M4 followed the method of Yusof et al. [22] according to the routes shown at Scheme 1. Generally, the carbonyl chloride reacted with ammonium isothiocyanate in acetone resulting carbonylisothiocyanate. The carbonylisothiocyanate then will be reacted with amine derivate and the mixture was put at reflux for $2.5 \mathrm{~h}$ then filtered off and left to evaporate at room temperature. For compound M1 (benzoyl chloride, $2.03 \mathrm{~g}$ (14.44 mmol), $\alpha$-alanin, $1.29 \mathrm{~g}$ (14.44 mmol), ammonium thiocyanate, $1.10 \mathrm{~g}$ (14.44 mmol); compound M2, (benzoyl chloride, $1.95 \mathrm{~g}$ (13.87 mmol), $\beta$-alanin, $1.24 \mathrm{~g}$ (13.87 mmol), ammonium thiocyanate, $1.06 \mathrm{~g}$ (13.87 mmol); compound M3, (4-chlorobutyryl chloride, $2.12 \mathrm{~g}$ (15.04 mmol), 2-chloroaniline, $1.92 \mathrm{~g}$ (15.04 mmol), ammonium thiocyanate, $1.14 \mathrm{~g}$ (15.04 mmol); compound M4, (4-chlorobutanoyl chloride, $2.05 \mathrm{~g}$ (14.54 mmol), 3-chloroaniline, $1.85 \mathrm{~g}$ (14.54 mmol), ammonium thiocyanate, $1.11 \mathrm{~g}(14.54 \mathrm{mmol})$.

\subsection{Characterization of the Newly-Synthesized Carbonyl Thiourea Derivatives}

2-(3-Benzoylthioureido)propanoic acid (M1). The title compound was obtained as colourless crystals in $38 \%$ yield after recrystallization from ethanol; IR (KBr pellets, v/ $\left.\mathrm{cm}^{-1}\right): 3389.22(\mathrm{O}-\mathrm{H}), 3234.82$ $(\mathrm{N}-\mathrm{H}), 1772.31(\mathrm{C}=\mathrm{O}), 1355.82(\mathrm{C}-\mathrm{N}), 782.93(\mathrm{C}=\mathrm{S})$; ${ }^{1} \mathrm{H}-\mathrm{NMR}\left(400.130 \mathrm{MHz}, \mathrm{DMSO}-d_{6}, \mathrm{ppm}\right): 1.42$ $\left(3 \mathrm{H}, \mathrm{d}, \mathrm{CH}_{3}\right), 3.52(1 \mathrm{H}, \mathrm{dd}, \mathrm{CH}), 7.27\left(1 \mathrm{H}, \mathrm{dd}, \mathrm{C}_{6} \mathrm{H}_{4}\right), 7.65\left(2 \mathrm{H}, \mathrm{m}, \mathrm{C}_{6} \mathrm{H}_{4}\right), 7.88\left(2 \mathrm{H}, \mathrm{d}, \mathrm{C}_{6} \mathrm{H}_{4}\right), 11.44$ $(1 \mathrm{H}, \mathrm{s}, \mathrm{NH}), 12.01(1 \mathrm{H}, \mathrm{s}, \mathrm{OH}), 12.20(1 \mathrm{H}, \mathrm{s}, \mathrm{NH}) ;{ }^{13} \mathrm{C}-\mathrm{NMR}\left(100.613 \mathrm{MHz}, \mathrm{DMSO}-d_{6} ; \mathrm{ppm}\right): 17.23$ 
$\left(\mathrm{CH}_{3}\right), 62.32(\mathrm{NHCH}), 126.82\left(\mathrm{CH}_{\mathrm{Ar}}\right), 129.09\left(\mathrm{CH}_{\mathrm{Ar}}\right), 130.24\left(\mathrm{NHC}_{\mathrm{Ar}}\right), 172.02(\mathrm{C}=\mathrm{O}), 175.52$ $\left(\mathrm{C}=\mathrm{O}_{\mathrm{OH}}\right), 180.43(\mathrm{C}=\mathrm{S})$.

3-(3-Benzoylthioureido)propanoic acid (M2). The title compound was obtained as colourless crystals in $52 \%$ yield after recrystallization from ethanol; IR (KBr pellets, $\left.\mathrm{v} / \mathrm{cm}^{-1}\right): 3324.61(\mathrm{O}-\mathrm{H}), 3203.79$ $(\mathrm{N}-\mathrm{H}), 1794.05(\mathrm{C}=\mathrm{O}), 1365.13(\mathrm{C}-\mathrm{N}), 774.02(\mathrm{C}=\mathrm{S}) ;{ }^{1} \mathrm{H}-\mathrm{NMR}\left(400.130 \mathrm{MHz}, \mathrm{DMSO}-d_{6}, \mathrm{ppm}\right): 2.63$ $\left(2 \mathrm{H}, \mathrm{dd}, \mathrm{NHCH}_{2} \mathrm{CH}_{2}\right), 3.67\left(2 \mathrm{H}, \mathrm{dd}, \mathrm{NHCH}_{2} \mathrm{CH}_{2}\right), 7.29\left(1 \mathrm{H}, \mathrm{dd}, \mathrm{C}_{6} \mathrm{H}_{4}\right), 7.64\left(2 \mathrm{H}, \mathrm{m}, \mathrm{C}_{6} \mathrm{H}_{4}\right), 7.87(2 \mathrm{H}$, d, $\left.\mathrm{C}_{6} \mathrm{H}_{4}\right), 11.54(1 \mathrm{H}, \mathrm{s}, \mathrm{NH}), 12.03(1 \mathrm{H}, \mathrm{s}, \mathrm{OH}), 12.23(1 \mathrm{H}, \mathrm{s}, \mathrm{NH}) ;{ }^{13} \mathrm{C}-\mathrm{NMR}(100.613 \mathrm{MHz}, \mathrm{DMSO}-$ $\left.d_{6}, \mathrm{ppm}\right): 34.25\left(\mathrm{NHCH}_{2} \mathrm{CH}_{2}\right), 43.18\left(\mathrm{NHCH}_{2}\right), 127.64\left(\mathrm{CH}_{\mathrm{Ar}}\right), 130.29\left(\mathrm{CH}_{\mathrm{Ar}}\right), 133.71\left(\mathrm{NHC}_{\mathrm{Ar}}\right)$, $172.84(\mathrm{C}=\mathrm{O}), 175.61\left(\mathrm{C}=\mathrm{O}_{\mathrm{OH}}\right), 181.32(\mathrm{C}=\mathrm{S})$.

$N$-(2-Chlorophenyl)-N'-(4-chlorobutanoyl)thiourea (M3). The title compound was obtained as colorless crystal in 73\% yield after recrystallization from dimethylformamide; IR ( $\mathrm{KBr}$ pellets, v/cm $\left.{ }^{-1}\right): 3164.31(\mathrm{~N}-\mathrm{H}), 1697.18(\mathrm{C}=\mathrm{O}), 1337.40(\mathrm{C}-\mathrm{N}), 723.53(\mathrm{C}=\mathrm{S}) ;{ }^{1} \mathrm{H}-\mathrm{NMR}(400.130 \mathrm{MHz}$, DMSO- $\left.d_{6}, \mathrm{ppm}\right): 2.02\left(2 \mathrm{H}, \mathrm{m}, \mathrm{COCH}_{2} \mathrm{CH}_{2} \mathrm{CH}_{2} \mathrm{Cl}\right), 2.65\left(2 \mathrm{H}, \mathrm{t}, \mathrm{COCH}_{2} \mathrm{CH}_{2} \mathrm{CH}_{2} \mathrm{Cl}\right), 3.66(2 \mathrm{H}, \mathrm{t}$, $\left.\mathrm{COCH}_{2} \mathrm{CH}_{2} \mathrm{CH}_{2} \mathrm{Cl}\right), 7.25\left(1 \mathrm{H}, \mathrm{d}, \mathrm{C}_{6} \mathrm{H}_{4}\right), 7.56\left(1 \mathrm{H}, \mathrm{t}, \mathrm{C}_{6} \mathrm{H}_{4}\right), 7.59\left(1 \mathrm{H}, \mathrm{t}, \mathrm{C}_{6} \mathrm{H}_{4}\right), 8.01\left(1 \mathrm{H}, \mathrm{d}, \mathrm{C}_{6} \mathrm{H}_{4}\right)$, $11.51(1 \mathrm{H}, \mathrm{s}, \mathrm{NH}), 12.45(1 \mathrm{H}, \mathrm{s}, \mathrm{NH}) ;{ }^{13} \mathrm{C}-\mathrm{NMR}\left(100.613 \mathrm{MHz}, \mathrm{DMSO}-d_{6}, \mathrm{ppm}\right): 27.28$ $\left(\mathrm{COCH}_{2} \mathrm{CH}_{2} \mathrm{CH}_{2} \mathrm{Cl}\right), 33.53\left(\mathrm{COCH}_{2} \mathrm{CH}_{2} \mathrm{CH}_{2} \mathrm{Cl}\right), 45.01\left(\mathrm{COCH}_{2} \mathrm{CH}_{2} \mathrm{CH}_{2} \mathrm{Cl}\right), 115.94\left(\mathrm{CH}_{\mathrm{Ar}}\right), 116.10$ $\left(\mathrm{CH}_{\mathrm{Ar}}\right), 127.41\left(\mathrm{NHC}_{\mathrm{Ar}}\right), 134.69\left(\mathrm{ClC}_{\mathrm{Ar}}\right), 175.92(\mathrm{C}=\mathrm{O}), 180.12(\mathrm{C}=\mathrm{S})$.

$N$-(3-Chlorophenyl)-N'-(4-chlorobutanoyl)thiourea, M4. The title compound was obtained as colourless crystal in 75\% yield after recrystallization from dimethylformamide; IR ( $\mathrm{KBr}$ pellets, v/cm $\left.{ }^{-1}\right): 3165.88(\mathrm{~N}-\mathrm{H}), 1694.05(\mathrm{C}=\mathrm{O}), 1325.09(\mathrm{C}-\mathrm{N}), 780.65(\mathrm{C}=\mathrm{S}) ;{ }^{1} \mathrm{H}-\mathrm{NMR}(400.130 \mathrm{MHz}$, DMSO- $\left.d_{6}, \mathrm{ppm}\right): 2.03\left(2 \mathrm{H}, \mathrm{m}, \mathrm{COCH}_{2} \mathrm{CH}_{2} \mathrm{CH}_{2} \mathrm{Cl}\right), 2.64\left(2 \mathrm{H}, \mathrm{t}, \mathrm{COCH}_{2} \mathrm{CH}_{2} \mathrm{CH}_{2} \mathrm{Cl}\right), 3.69(2 \mathrm{H}, \mathrm{t}$, $\left.\mathrm{COCH}_{2} \mathrm{CH}_{2} \mathrm{CH}_{2} \mathrm{Cl}\right), 7.24\left(1 \mathrm{H}, \mathrm{d}, \mathrm{C}_{6} \mathrm{H}_{4}\right), 7.29\left(1 \mathrm{H}, \mathrm{t}, \mathrm{C}_{6} \mathrm{H}_{4}\right), 7.62\left(1 \mathrm{H}, \mathrm{d}, \mathrm{C}_{6} \mathrm{H}_{4}\right), 7.96\left(1 \mathrm{H}, \mathrm{s}, \mathrm{C}_{6} \mathrm{H}_{4}\right)$, $11.47(1 \mathrm{H}, \mathrm{s}, \mathrm{NH}), 12.42(1 \mathrm{H}, \mathrm{s}, \mathrm{NH}) .{ }^{13} \mathrm{C}-\mathrm{NMR}\left(100.613 \mathrm{MHz}, \mathrm{DMSO}-d_{6}, \mathrm{ppm}\right): 27.25$ $\left(\mathrm{COCH}_{2} \mathrm{CH}_{2} \mathrm{CH}_{2} \mathrm{Cl}\right), 45.04\left(\mathrm{COCH}_{2} \mathrm{CH}_{2} \mathrm{CH}_{2} \mathrm{Cl}\right), 33.54\left(\mathrm{COCH}_{2} \mathrm{CH}_{2} \mathrm{CH}_{2} \mathrm{Cl}\right), 115.70\left(\mathrm{CH}_{\mathrm{Ar}}\right), 115.92$ $\left(\mathrm{CH}_{\mathrm{Ar}}\right), 127.31\left(\mathrm{NHC}_{\mathrm{Ar}}\right), 134.67\left(\mathrm{ClC}_{\mathrm{Ar}}\right), 175.81(\mathrm{C}=\mathrm{O}), 179.89(\mathrm{C}=\mathrm{S})$.

\subsection{Determination of $I C_{50}$ Values}

Thiourea derivatives were prepared by dissolving $1 \mathrm{mg}$ of compound in $10 \mu \mathrm{L}$ absolute DMSO (Fisher Scientific, Schwerte, UK) and added with $990 \mu \mathrm{L}$ sterile culture media, to make a $1 \mathrm{mg} \cdot \mathrm{mL}^{-1}$ solution. Dissolution was facilitated by mild sonication in a sonicator bath (Branson, CT, USA) for two minutes. Then, $100 \mu \mathrm{L}$ of the $1 \mathrm{mg} \cdot \mathrm{mL}^{-1}$ samples were further diluted with $900 \mu \mathrm{L}$ of culture media to produce compound stocks of $100 \mu \mathrm{g} \cdot \mathrm{mL}^{-1}$ with $0.1 \%$ DMSO. These thiourea compounds solutions were freshly prepared before conducting every experiment. The experiment was conducted in 96-well plates (Nunc, Schwerte, Germany). Nine different concentrations of compounds were prepared to give final concentrations of compounds as follows: 100, 50, 25, 12.5, 6.25, 3.13, 1.56, 0.78 and $0.39 \mu \mathrm{g} \cdot \mathrm{mL}^{-1}$. Each concentration was prepared in three replicates. Chlorhexidine gluconate (Raza Manufacturing, Kuala Lumpur, Malaysia) which is a common agent used for treatment of amoebic keratitis infections was used as the positive control. The nine final concentrations of chlorhexidine used for the assays were as follows: $200,100,50,25,12.5,6.25,3.13,1.56$ and $0.78 \mu \mathrm{M}$. 
The number of viable Acanthamoeba for treatment was calculated by using a hemocytometer with trypan blue. A calculated amount of $\sim 10^{4}$ viable cells $\cdot \mathrm{mL}^{-1}$ was used as the number or concentration of Acanthamoeba of which the cells would reach their confluence stage after $72 \mathrm{~h}$ of incubation without excessive growth [41]. Negative control was $10^{4}$ cells $\cdot \mathrm{mL}^{-1}$ of healthy Acanthamoeba without any treatment. The plates were later incubated at $30{ }^{\circ} \mathrm{C}$ for $72 \mathrm{~h}$. After incubation, the staining process was done following Wright's technique [42]. The final solutions from all wells were read for their absorbance at $490 \mathrm{~nm}$ by ELISA microplate reader (Tecan, Victoria, Australia). The readings were plotted in GraphPad Prism software version 5.03 (GraphPad Inc., San Diego, CA, USA) to give a nonlinear sigmoidal dose-response curve. The cytotoxicity was expressed as the $\mathrm{IC}_{50}$ value that represents the concentration of a compound that is required for inhibition of 50\% of an Acanthamoeba population in vitro. A $t$-test (SPSS, version 11.5., SSPS Inc., Armonk, NY, USA) was done to compare the mean values between untreated and treated cultures with $p<0.05$ considered as statistically significant.

\subsection{Observation of Changes in Acanthamoeba Morphology}

Acanthamoeba both untreated and treated with the compounds were observed for their morphological changes. Acanthamoeba $\left(10^{4}\right.$ cells $\left.\cdot \mathrm{mL}^{-1}\right)$ were treated with the thiourea compounds and the positive control (chlorhexidine) at their $\mathrm{IC}_{50}$ concentration in 6-well-plates, which were then incubated at $30{ }^{\circ} \mathrm{C}$ for $72 \mathrm{~h}$. After the incubation, the morphology of Acanthamoeba was observed directly from the well plates under an inverted microscope (Leica Leitz, Wetzlar, Germany). Images were captured by using Image Master Video Test Package (Trioptics, Wetzlar, Germany) software.

\subsection{Evaluation of Acanthamoeba Membrane Integrity}

Acanthamoeba were adjusted to $10^{4}$ cells in $1 \mathrm{~mL}$ culture media prior to the treatment with thiourea compounds and chlorhexidine, at their $\mathrm{IC}_{50}$ concentration in $25-\mathrm{cm}^{2}$ tissue culture flasks and later incubated at $30{ }^{\circ} \mathrm{C}$ for $72 \mathrm{~h}$. After the incubation, the cell suspension was resuspended, harvested and transferred into Eppendorf tubes for AO/PI staining. Stock solution for AO/PI staining was prepared by adding AO $\left(2 \mu \mathrm{L}, 1 \mathrm{mg} \cdot \mathrm{mL}^{-1}\right.$, Sigma, St. Louis, MO, USA $)$ and PI $\left(2 \mu \mathrm{L}, 1 \mathrm{mg} \cdot \mathrm{mL}^{-1}\right.$, Sigma $)$ to give a mixture of 1:1 (v/v) ratio in $996 \mu \mathrm{L}$ phosphate buffered saline (PBS, Sigma). The AO/PI staining protocol followed the technique by Mascotti et al. [43]. Both dyes are light sensitive therefore they were handled in a dark room. The harvested Acanthamoeba cells were centrifuged at 1,000 rpm for $5 \mathrm{~min}$ at $4{ }^{\circ} \mathrm{C}$. The supernatant were discarded and pellets were washed with PBS and re-centrifuged at 1,000 rpm for $5 \mathrm{~min}$. The fresh pellets were mixed with $20 \mu \mathrm{L}$ of AO/PI staining from the stock and transferred onto microscope slides and viewed under a fluorescence microscope (Leica Dmire, Wetzlar, Germany) in dark condition. Images were captured by Image Master Video Test Package software (Trioptics).

\section{Conclusions}

The results of this study indicate that the newly-synthesized carbonyl thiourea derivatives provide promising anti-Acanthamoeba properties against pathogenic A. castellanii and A. polyphaga. Based on their low $\mathrm{IC}_{50}$ values the compounds 2-(3-benzoylthioureido)propanoic acid (M1) and 
3-(3-benzoylthioureido)propanoic acid (M2) exhibited stronger anti-amoebic activity compared to the other tested compounds used, and this finding correlates with the presence of amino acids groups in their molecular structures. All thiourea derivatives used in this study were proven to cause Acanthamoeba to become inactive, and can disrupt the integrity of the amoeba cell membrane. Therefore, these new carbonyl thiourea derivatives can be suggested as future anti-amoebic agents.

\section{Acknowledgments}

The authors are greatly appreciative to Ministry of Science, Technology and Innovation, Malaysia (MOSTI) for the research financial support through E-Science Fund (52022) and The Institute of Oceanography, Universiti Malaysia Terengganu for providing the space and facilities to conduct this work.

\section{Conflicts of Interest}

The authors declare no conflict of interest.

\section{References}

1. De Jonckheere, J.F. Ecology of Acanthamoeba. Rev. Infect. Dis. 1991, 13, S385-S387.

2. Page, F.C. A New Key to Freshwater and Soil Gymnamoebae. In Freshwater Biological Association; Culture Collection of Algae and Protozoa: Ambleside, Cumbria, UK, 1988; p. 122.

3. Narasimhan, S.; Madhavan, H.; Therese, L. Development and application of an in vitro susceptibility test for Acanthamoeba species isolated from keratitis to polyhexamethylene biguanide and chlorhexidine. Cornea 2002, 21, 203-205.

4. Marciano-Cabral, F.; Cabral, G. Acanthamoeba spp. as agents of disease in humans. Clin. Microbiol. Rev. 2003, 16, 273-307.

5. Elder, M.J.; Dart, J.K.G. Chemotherapy for Acanthamoeba keratitis. Lancet 1995, 345, 791-792.

6. Larkin, D.F.P.; Kilvington, S.; Dart, J.K.G. Treatment of Acanthamoeba keratitis with polyhexamethylene biguanide. Ophthalmology 1992, 99, 185-191.

7. Seal, D.V. Acanthamoeba keratitis update-Incidence, molecular epidemiology and new drugs for treatment. Eye 2003, 17, 893-905.

8. Murdoch, D.; Gray, T.B.; Cursons, R.; Parr, D. Acanthamoebakeratitis in New Zealand, including two cases with in vivo resistance to polyhexamethylene biguanide. Aust. New Zeal. J. Ophthalmol. 1998, 26, 231-236.

9. Turner, N.A.; Russell, A.D.; Furr, J.R.; Lloyd, D. Emergence of resistance to biocides during differentiation of Acanthamoeba castellanii. J. Antimicrob. Chemother. 2000, 46, 27-34.

10. Ficker, L.; Seal, D.; Warhurst, D.; Wright, P. Acanthamoeba keratitis: Resistance to medical therapy. Eye 1990, 4, 835-838.

11. Abid, M.; Agarwal, S.M.; Azam, A. Synthesis and anti-amoebic activity of metronidazole thiosemicarbazone analogues. Eur. J. Med. Chem. 2008, 43, 2035-2039. 
12. Budakoti, A.; Bhat, A.R.; Athar, F.; Azam, A. Syntheses and evaluation of 3-(3-bromophenyl)-5phenyl-1-(thiazolo[4,5-b]quinoxaline-2-yl)-2pyrazoline derivatives. Eur. J. Med. Chem. 2008, 43, 1749-1757.

13. Ziegler-Skylakakis, K.; Nill, S.; Pan, J.F.; Andrae, U. S-Oxygenation of thiourea results in the formation of genotoxic products. Environ. Mol. Mutagen. 1998, 31, 362-373.

14. Khan, S.A.; Singh, N.; Saleem, K. Synthesis, characterization and in vitro antibacterial activity of thiourea and urea derivatives of steroids. Eur. J. Med. Chem. 2008, 43, 2272-2277.

15. Zhong, Z.; Xing, R.; Liu, S.; Wang, L.; Chai, S.; Li, P. Synthesis of acyl thiourea derivatives of chitosan and their anti-microbial activities in vitro. Carbohydr. Res. 2008, 343, 566-570.

16. Eweis, M.; Elkholy, S.S.; Elsabee, M.Z. Antifungal efficacy of chitosan and its thiourea derivatives upon the growth of some sugar-beet pathogens. Int. J. Biol. Macromol. 2006, 38, 1-8.

17. Chen, S.; Wu, G.; Zeng, H. Preparation of high anti-microbial activity chitosan- $\mathrm{Ag}^{+}$complex. Carbohydr. Polym. 2005, 60, 33-38.

18. Turan-Zitouni, G.; Sıvacı, D.M.; Kaplancıklı, Z.A.; Özdemir, A. Synthesis and anti-microbial activity of some pyridinyliminothiazoline derivatives. Il Farmaco 2002, 57, 569-572.

19. Phetsuksiri, B.; Jackson, M.; Scherman, H.; McNeil, M.; Besra, G.S.; Baulard, A.R.; Slayden, R.A.; DeBarber, A.E.; Barry, C.E., III; Baird, M.S.; et al. Unique mechanism of action of the thiourea drug isoxyl on Mycobacterium tuberculosis. J. Biol. Chem. 2003, 278, 53123-53130.

20. Paynter, O.E.; Burin, G.J.; Jaeger, R.B.; Gregorio, C.A. Goitrogens and thyroid follicular cell neoplasia. Evidence for a threshold process. Regul. Toxicol. Pharmacol. 1988, 8, 102-119.

21. Yusof, M.S.M.; Yamin, B.M. 3-(3-Benzoylthioureido) propionic acid. Acta Crystallogr. 2003, E59, o828-o829.

22. Yusof, M.S.M.; Embong, N.F.; Yamin, B.M.; Ngah, N. 1-(4-Chlorobutanoyl)-3-(2-chloro phenyl)thiourea. Acta Crystallogr. 2012, E68, o1536.

23. Deharo, E.; Bourdy, G.; Quenevo, C.; Munoz, V.; Ruiz, G.; Sauvain, M. A search for natural bioactive compounds in Bolivia through a multi disciplinary sciences approach. Part V. Evaluation of the antimalarial activity of plants used by the Tacana Indians. J. Ethnopharmacol. 2001, 77, 91-98.

24. McBride, J.; Ingram, R.P.; Henriquez, F.L.; Roberts, C.W. Development of colorimetric microtiter plate assay for assessment of anti-microbials against Acanthamoeba. J. Clin. Microbiol. 2005, 43, 629-634.

25. Patnaik, P. A Comprehensive Guide to the Hazardous Properties of Chemical Substances; Wiley-Interscience: Hoboken, NJ, USA, 2007; p. 904.

26. Fustero, S.; Salavert, E.; Pina, B.; de Arellano, C.R.; Asensio, R. Novel strategy for the synthesis of fluorinated $\beta$-amino acid derivatives from $\Delta^{2}$-oxazolines. Tetrahedron 2001, 57, 6475-6486.

27. Ye, Y.H.; Huang, Y.S.; Wang, Z.Q.; Chen, S.M.; Tian, Y. Synthesis of new amino acid and peptide derivatives of estradiol and their binding affinities for the estrogen receptor. Steroids 1993, 58, 35-39.

28. Patel, N.B.; Shaikh, F.M. Synthesis and anti-microbial activity of new 4-thiazolidinone derivatives containing 2-amino-6-methoxybenzothiazole. Saudi Pharm. J. 2010, 18, 129-136.

29. Bowers, B.; Korn, E.D. The fine structure of Acanthamoeba castellanii, kinetics and morphology. I. The Trophozoite. J. Cell Biol. 1968, 39, 95-111. 
30. Khan, N.A. Pathogenicity, morphology, and differentiation of Acanthamoeba. Curr. Microbiol. 2001, 43, 391-395.

31. Bowers, B.; Korn, E.D. Localization of lipophosphonoglycan on both sides of Acanthamoeba plasma membrane. J. Cell Biol. 1974, 62, 533-540.

32. Khan, N.A. Emerging Protozoan Pathogens; Taylor \& Francis Group: Oxford, UK, 2008; pp. 5-24.

33. Weisman, R.A. Differentiation in Acanthamoeba castellanii. Annu. Rev. Microbiol. 1976, 30, 189-219.

34. Coder, D.M. Assessment of cell viability. In Current Protocols in Cytometry, 2nd ed.; Wiley: New York, NY, USA, 1997; pp. 8-11.

35. Darzynkiewicz, Z.; Juan, G.; Li, X.; Gorczyka, W.; Murakami, T.; Traganos, F. Cytometry in cell necrobiology: Analysis of apoptosis and accidental cell death (necrosis). Cytometry 1997, 27, 1-20.

36. Riss, T.L.; Moravec, R.A. Use of multiple assay endpoints to investigate the effects of incubation time, dose of toxin, and plating density in cell-based cytotoxicity assays. Assay Drug Dev. Technol. 2004, 2, 51-62.

37. Arnkt-Jovin, D.J.; Jovin, T.M. Fluorescence labeling and microscopy of DNA. Methods Cell Biol. 1989, 30, 417-448.

38. Puranam, K.L.; Boustany, R.M. Assessment of cell viability and histochemical methods in apoptosis. In Apoptosis in Neurobiology; Hannun, Y.A., Boustany, R.M., Eds.; CRC Press: Washington, DC, USA, 1999; p. 78.

39. Perrine, D.; Chenu, J.P.; Georges, P.; Lancelot, J.C.; Saturnino, C.; Robba, M. Amoebicidal efficiencies of various diamidines against two strains of Acanthamoeba polyphaga. Antimicrob. Agents Chemother. 1995, 39, 339-342.

40. Nakisah, M.A.; Ida Muryany, M.Y.; Fatimah, H.; Nor Fadilah, R.; Zalilawati, M.R.; Khamsah, S.; Habsah, M. Anti-amoebic properties of a Malaysian marine sponge Aaptos sp. on Acanthamoeba castellanii. World J. Microbiol. Biotechnol. 2012, 28, 1237-1244.

41. Asiri, S.; Ogbunade, P.O.J.; Warhust, D.C. In vitro assessment of susceptibility of Acanthamoeba polyphaga to drugs using combined methods of dye-binding assay and uptake of radiolabeled adenosine. Int. J. Parasitol. 1994, 24, 975-980.

42. Wright, C.W.; O’Neill, M.J.; Phillipson, J.D.; Warhurst, D.C. Use of microdilution to assess in vitro anti-amoebic activities of Bruceajavanica fruits, Simaroubaamara Stem, and a number of Quassinoids. Antimicrob. Agents Chemother. 1988, 32, 1725-1729.

43. Mascotti, K.; McCullough, J.; Burger, S.R. HPC viability measurement: Trypan blue versus acridine orange and propidium iodide. Transfusion 2000, 40, 693-696.

Sample Availability: Samples of the compoundsare available from the authors.

(C) 2014 by the authors; licensee MDPI, Basel, Switzerland. This article is an open access article distributed under the terms and conditions of the Creative Commons Attribution license (http://creativecommons.org/licenses/by/3.0/). 